\title{
Treatment strategies for aorta-right ventricular fistula associated with aortic and/or mitral valve replacements: a case report with a review of the literature
}

Strategie leczenia przetoki między aortą a prawą komorą serca związanej z operacją wymiany zastawki aortalnej i/lub mitralnej: opis przypadku i przegląd piśmiennictwa

Hekim Karapinar', Zekeriya Kucukdurmaz', Hasan Ali Gumrukcuoglu², Hidayet Kayancicek², Ibrahim Gul', Ahmet Yilmaz ${ }^{1}$

${ }^{1}$ Cumhuriyet University Medical School, Cardiology Department, Sivas, Turkey

2Van High Speciality Hospital, Van, Turkey

Post Kardiol Interw 2011; 7, 2 (24): 182-184 DOI: $10.5114 /$ pwki.2011.23172

\begin{abstract}
We report a case of aorta-right ventricular fistula associated with aortic and mitral valve replacements. We considered it as a paravalvular leakage. Aorta-right ventricular fistula is a very rare variant of paravalvular leakage. We discuss the aetiology, diagnosis, and preventive and therapeutic options in the modern era.
\end{abstract}

Key words: aorta, right ventricle, fistula, paravalvular

\section{Streszczenie}

Przedstawiamy przypadek pacjenta z przetoką między aortą a prawą komorą związaną z operacją wymiany zastawki aortalnej i mitralnej. Była ona rozpatrywana jako przeciek okołozastawkowy. Przetoka między aortą a prawą komorą jest bardzo rzadką odmianą przecieku okołozastawkowego. Omawiamy jej etiologię, diagnostykę oraz obecne strategie zapobiegania i leczenia.

Słowa kluczowe: aorta, prawa komora, przetoka, ubytek okołozastawkowy

\section{Introduction}

Aorta-right ventricular (Ao-RV) fistulas are seen rarely. Most of these cases are caused by sinus of Valsalva rupture, endocarditis, and less frequently by trauma or are associated with valve replacement [1, 2]. We report a case of Ao-RV fistula associated with aortic and mitral valve replacements and considered as a paravalvular leakage.

\section{Case report}

A 58-year-old male who had mechanical mitral and aortic valves was admitted to our clinic with exertional dyspnoea for 3 years. He was free of any illness rather than the previous rheumatic heart disease. His admittance heart rate was 87 per minute, arterial blood pressure was 130/70 mmHg and the body temperature was $36.7^{\circ} \mathrm{C}$. Mechanical valve sounds were audible and systolic and diastolic murmur was heard at the precordial area. The rest of the physical examinations were normal. Biochemical parameters were all in normal ranges and the haemoglobin was $11.2 \mathrm{mg} / \mathrm{dl}$. The prothrombin time was $18 \mathrm{~s}$ and the international normalized ratio (INR) was 1.3, which are in the ineffective range. Electrocardiography showed normal sinus rhythm. He was operated on for severe aortic and mitral stenosis and mitral regurgitation, and the native valves were replaced by bileaflet St. Jude mechanical valves (St. Jude Medical Inc, Minneapolis, MN, USA) 3 years ago. Transthoracic echocardiography (TTE) revealed normal function of mechanical aortic and mitral valves, modest impaired systolic left ventricle function (EF 40\%), dilated 
right heart and enlarged hepatic veins. Colour Doppler revealed an abnormal jet in the right ventricle (fig. 1). Then CW Doppler revealed a systole-diastolic jet from the aorta toward the right ventricular apex (fig. 2). So we decided to perform transesophageal echocardiography (TEE) for further investigation. TEE supported the aorta-right ventricular fistula through a $20 \times 8 \mathrm{~mm}$, crescent, aortic paravalvular defect (fig. 3). So we performed cardiac catheterization to confirm the diagnosis and to investigate the associated pathologies. Nothing apart from the large aorta-right ventricular fistula was seen, nor was significant

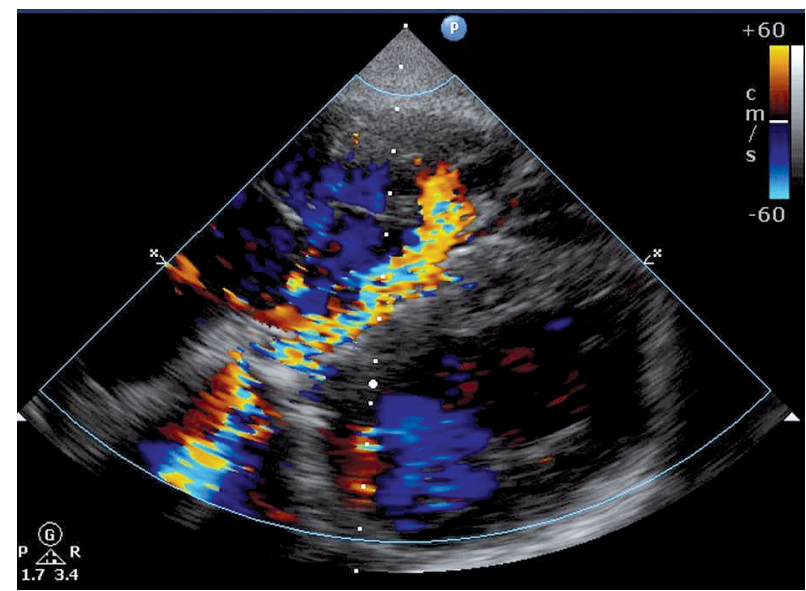

Fig. 1. Aorta-right ventricular fistula jet by colour Doppler from subcostal window

Ryc. 1. Przetoka między aorta a prawa komora $z$ widoczna fala przeptywu $w$ badaniu metoda dopplera kolorowego w projekcji podmostkowej

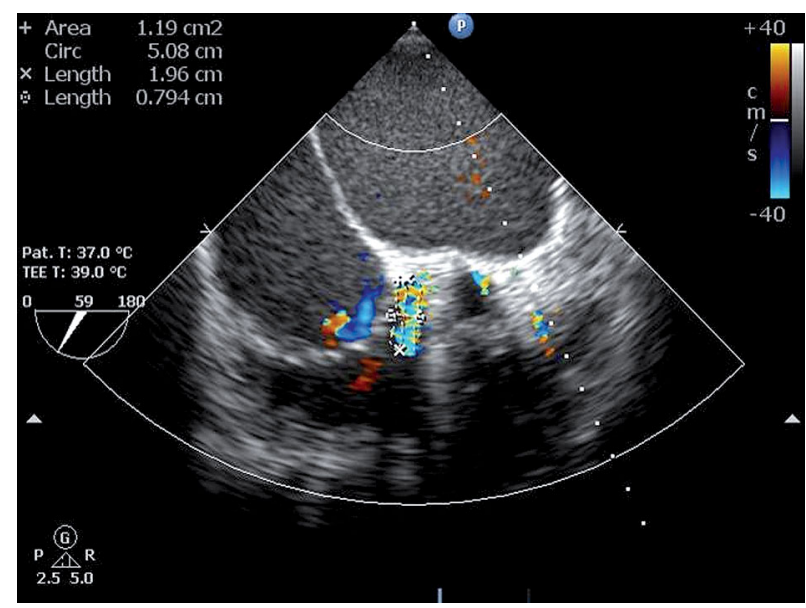

Fig. 3. Aortic paravalvular defect is seen at the right heart border of the mechanical valve annulus at $60^{\circ}$ by transoesophageal echocardiography

Ryc. 3. Ubytek okołozastawkowy zastawki aortalnej widoczny na granicy prawokomorowej pierścienia zastawki mechanicznej pod katem $60^{\circ}$ $w$ badaniu echokardiograficznym przezprzetykowym coronary artery disease observed (fig. 4). We recommended him percutaneous closure of the fistula but he refused this option as well as the re-do operation, after optimizing his medical therapy he was discharged. Unfortunately he died at the ninth month of the follow-up.

\section{Discussion}

Aorta-RV fistulas are seen infrequently, and limited cases have been reported caused by valve replacement [26]. latrogenic injury of the septum, aggressive debridement of the annulus and inappropriate suturing of the

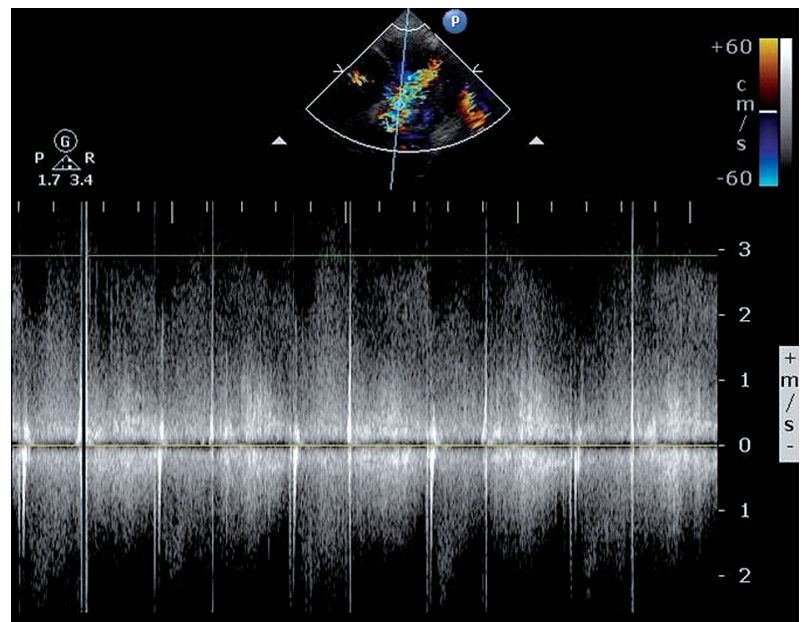

Fig. 2. Systole-diastolic jet by CW Doppler from subcostal window

Ryc. 2. Skurczowo-rozkurczowa fala przeptywu $w$ badaniu dopplerowskim fali ciagtej w projekcji podmostkowej

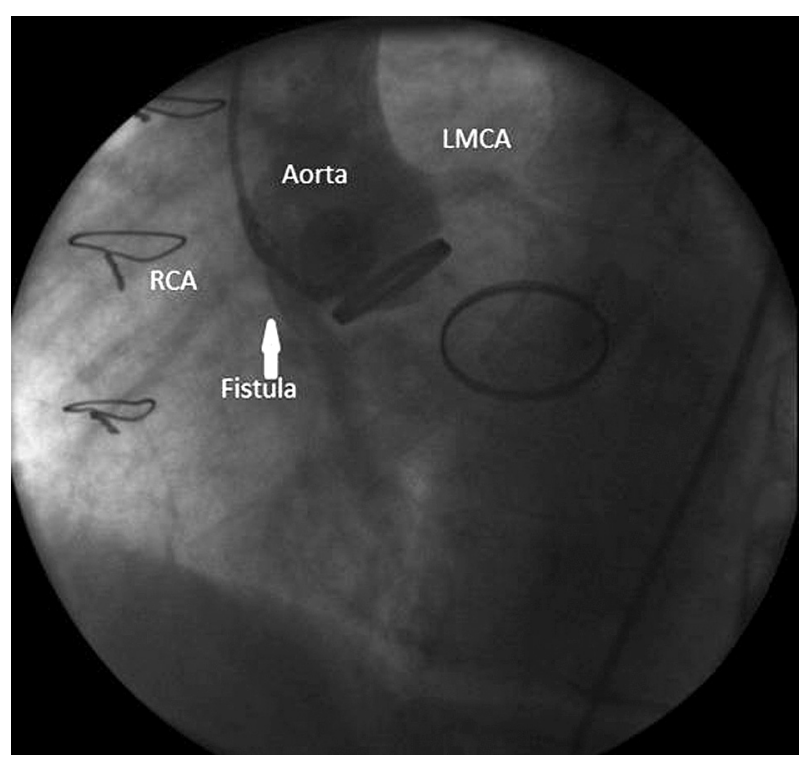

Fig. 4. Aorta-right ventricular fistula is seen in the aortography from left anterior oblique view

Ryc. 4. Przetoka między aorta a prawa komora widoczna w aortografii w projekcji przedniej skośnej lewej 
mechanical valve onto the membranous portion of the ventricular septum may cause the fistula. Also primary suture failure (dehiscence) and infective endocarditis associated paravalvular leakages (PVL) may be seen [5]. Intraoperative TEE may reduce the risk of PVL, by identifying residual leaks for the surgeon to address before chest closure [7].

Presentation of aorta-RV fistulas is diverse in the aetiology, size and acute or chronic nature of the fistula. Fever may be seen in the infective states. Right heart failure may be seen in chronic phases due to RV pressure and volume overloads. Left ventricular dilatation and failure may be seen due to high output as well as in the patent ductus arteriosus or peripheral A-V fistulas [8]. Diastolic murmur may be heard in patients with native valves but metallic sounds of the mechanical valves may mask it. High gradients may be observed across the mechanical valves due to the high output states in the echocardiography. Anaemia, icterus and elevated lactate dehydrogenize level may be found because of the haemolysis [2, 9]. Diagnosis may be an incidental finding by the evaluation of left/right heart failure or routine follow-up by TTE. Once the clinician becomes suspicious of it, the diagnosis may need special attention and awareness [3]. Confirmation of the diagnosis may be done by catheterization, cardiac magnetic resonance or multi-slice computerized tomography.

The decision for the therapy is made depending on the size and clinical characteristics of the patient. Haemolytic anaemia, pulmonary hypertension, and right and/or left heart failure are the indications for treatment of the fistula. Aorta-RV fistulas and other paravalvular leakages are, conventionally, treated by open heart surgery. Experiences are limited for surgical treatment due to the infrequency of the disease. Post-operative fistulas such as paravalvular leakages have more risk due to the possible associated cardiovascular morbidities such as depressed ventricular function, pulmonary hypertension so the re-do operation [2]. Percutaneous transcatheter is a novel choice for therapy but experiences are also limited like the surgical choice. It was applied by several physicians with different devices including a coil [9], Amplatzer duct occluder [6], Amplatzer atrial septal occluder [10], Amplatzer muscular ventricular septal defect occluder [11] and Amplatzer vascular plug [12] Most of these applications were successful although complications were also reported $[13,14]$.

\section{Conclusions}

Paravalvular leakage is an important and sometimes devastating complication of mechanical valve replacement. Avoiding PVL is simpler than the treatment. Generalization of the intra-operative TEE application to all valve replacement and other intra-cardiac repairs is the cornerstone of prevention of PVL.

\section{Acknowledgements}

The authors do not report any conflict of interest regarding this work.

\section{References}

1. Edwards JE, Burchell HB. The pathological anatomy of deficiencies between the aortic root and the heart, including aortic sinus aneurysms. Thorax 1957; 12: 125-139.

2. Miller DL, Morris JJ, Schaff HV, et al. Reoperation for aortic valve periprosthetic leakage: identification of patients at risk and results of operation. J Heart Valve Dis 1995; 4: 160-165.

3. Cay S, Tufekcioglu O, Ozturk S. A rare complication of aortic valve replacement surgery- aorta-right ventricular fistula: an evaluation with real-time multiplane echocardiography. Anadolu Kardiyol Derg 2007; 7: 240-241.

4. Roy D, Saba S, Grinberg I. Aorto-right ventricular fistula: a late complication of aortic valve replacement. Tex Heart Inst J 1999; 26: $140-142$

5. Lorenz J, Reddy CVR, Khan R, et al. Aorto-right ventricular shunt following aortic valve replacement. Chest 1983; 83: 922-925.

6. Dussaillant GR, Romero L, Ramírez A, et al. Successful percutaneous closure of paraprosthetic aorto-right ventricular leak using the Amplatzer duct occluder. Catheter Cardiovasc Interv 2006; 67: 976-980.

7. Shapira Y, Vaturi M, Weisenberg DE. Impact of intraoperative transesophageal echocardiography in patients undergoing valve replacement. Ann Thorac Surg 2004; 78: 579-583.

8. Samuels LE, Kaufman MS, Rodriguez-Vega J, et al. Diagnosis and management of traumatic aorto-right ventricular fistulas. Ann Thorac Surg 1998; 65: 288-292.

9. Moscucci M, Deeb GM, Bach D, et al. Coil embolization of a periprosthetic mitral valve leak associated with severe hemolytic anemia. Circulation 2001; 104: E85-E86.

10. Phillips SA, Thompson A, Abu-Halimah A, et al. Percutaneous closure of aortic prosthetic paravalvular regurgitation with two amplatzer septal occluders. Anesth Analg 2009; 108: 437-8.

11. Nikolic A, Schranz D, Hristov N, et al. Amplatzer occlusion of paravalvular leak of mitral mechanical prosthesis following a reoperation for thrombosed mitral mechanical prosthesis. Interact Cardiovasc Thorac Surg 2008; 7: 941-942.

12. Nietlispach F, Johnson M, Moss RR. Transcatheter closure of paravalvular defects using a purpose-specific occluder. JACC Cardiovasc Interv 2010; 3: 759-765.

13. Yuan SM, Shinfeld A, Raanani E. Displacement of the Amplatzer occluder device from the mitral paraprosthetic leak. Interact Cardiovasc Thorac Surg 2008; 7: 1131-1133.

14. Brilakis ES, Collins LJ, Obel O, et al. Mechanical valve dysfunction after percutaneous perimitral leak closure: salvage by percutaneous occluder retrieval. Catheter Cardiovasc Interv 2010; 75: 876-881. 